\title{
MILLED BAR VERSUS RIGID TELESCOPIC ATTACHMENT FOR MANDIBULAR IMPLANT SUPPORTED OVERDENTURES. A STUDY OF PATIENT SATISFACTION AND ORAL HEALTH QUALITY OF LIFE
}

\author{
Ahmed Samir Ahmed Khair Allah* and Ahmad Fathalla Shawky**
}

\begin{abstract}
Aim: This investigation aimed to evaluate participant satisfaction and quality of life of Milled bar versus rigid telescopic attachment for mandibular implant supported overdentures.

Materials and methods: Eight edentulous participants who unsatisfied with the retention and stability of existing mandibular prosthesis received 4 implants in the interforminal area of the mandible using computer guided flapless surgical approach. After 3 months, implants were connected to overdentures with rigid telescopic $(n=4)$ or milled bar $(n=4)$ attachments. After 3 months of addaptation, patient satisfaction was measured using Visual analouge scale and Oral health related quality of life (OHEQoL) was measured using Oral health impact profile (OHIP-14). Comparison of data between groups were made using MannWhiteny test.
\end{abstract}

Results: Milled bar showed significant higher satisfaction with overdenture retention than telescopic overdentures, while the later showed significant higher satisfaction with overdenture cleaning compared to milled bar. No significant differnce between the attachments was noted regarding other questionaire of VAS. Regarding OHIP, telescopic overdentures showed higher satisfaction regarding pronounciation of sounds, and comfort on eating than milled bars. No significant differnce between overdentures were noted for other OHIP questions

Conclusion: Within the limits of this study, both telescopic and milled bar mandibular overdentures achieve high patient satisfaction and oral health related quality of life. However, milled bar overdentures are advantageous in terms of overdenture retention and telescopic overdentures are advantageous in terms of cleaning, comfort on eating and pronunciation of sounds.

KEY WORDS: Milled bar, telescopic, attachment, implant overdentures, patient satisfaction.

\footnotetext{
* Associate professor of Removable Prosthodontics, Faculty of Dentistry Mansoura University

** Associate professor of Removable Prosthodontics, Faculty of Dentistry Beni- Suef University
} 


\section{INTRODUCTION}

According to consensus statements on overdentures ${ }^{1,2}$, the 2 implant retained mandibular overdentures are considered a regular and reliable treatment alternative to conventional mandibular denture as it is simple, cost effective, provide adequate retention and stabilization of dentures, and achieves high levels of patient satisfaction. However, this type of overdentures depends on the ridge and mucosa for support, and use implants mainly for retention. In patients with mandibular ridge atrophy, thin knife edge residual ridges, or when maxillary natural dentition exists, superficial myelohyoid ridge or mental nerves, the mucosal support creates many problems such as pain, mucosal discomfort and irritation and lack of patient satisfaction ${ }^{3,4}$. The totally implant born overdentures have many merits including; less mucosal pressure and irritation ${ }^{5}$, increased support, retention and stability of the overdenture and reduction of bone resorption due to reduction of forces on the residual ridges ${ }^{6}$. Moreover, implant supported overdentures provide stable occlusion, reduce prosthetic problems and complications ${ }^{7}$, and provide excellent masticatory force, chewing efficiency and electromyographic activity compared to implant retained overdentures ${ }^{8}$. Totally implant born overdentures are preferred over fixed prosthesis due to lower costs, ease of performing adequate oral hygiene, ease in managing prosthetic complications, ability to correct phonetic and aesthetic problems such as reduced lip support, and long clinical crowns ${ }^{9}$ The use of 4 interforaminal implants to support a mandibular overdenture optimizes the stress distribution throughout all the components and enhances denture stability and retention..$^{10}$, ${ }^{11}$. It is well documented with longitudinal studies that insertion of the implants in the interforaminal region of the mandibule to support mandibular overdentures is associated with high success rate of implants due to favourable quantity and quality of remaining alveolar bone and location away from vital structures ${ }^{12-15}$
Implant supported milled bar over-denture present a rigid anchorage system, limiting its lateral and rotational movements and distributes stresses evenly on the implants. Movement of milled bar overdenture is limited to path of removal only which is favorable for preventing prosthetic maintenance (clip activation) and jaw resorption. ${ }^{16-22}$ The fact that the prosthesis is detachable by the patient allows easier oral hygiene, and increased masticatory efficiency. Furthermore, superior esthetics and phonetics are noticeable benefits ${ }^{16}$. It also present a cheaper alternative to fixed restorations and can be removed to avoid nocturnal parafunction ${ }^{23}$. Furthermore, in cases with mandibular atrophy with unfavorable maxilla-mandibular relations, it provides facial support, restore soft tissue loss, and make oral hygiene more easy than fixed prostheses. Such overdentures offer the advantages of removable prosthesis with stability and retention of fixed prostheses ${ }^{23}$

Telescopic attachments are composed of primary (inner) and secondary (outer) crowns. Telescopic attachments may be rigid ones which include friction parallel walls or the conical, and the non rigid (resilient) ones. Rigid telescopic crowns direct occlusal contact between inner and outer copings. They achieve retention using friction of parallel-sided milled surfaces of the inner and outer crowns during insertion and removal. Conical (tapered) telescope crowns exhibit friction only when completely seated using a "wedging effect." ${ }^{24-26}$. Telescopic attachments provide several advantages compared to bar attachments such as easier oral hygiene, selfinsertion ability in patients with handling problems, high retention by friction, excellent denture support and stability especially in patients with atrophied ridges, and minimal restriction of tongue space s6-28 $^{26}$

Patient-reported outcomes is becoming progressively noticeable in assessing the result of prosthodontic treatment. The most commonly used perception method for evaluation of implant intervention in edentulous patients is oral health-related quality of life (OHRQoL). Patient satisfaction is another outcome that permits quantification of patients' 
opinion with respect to the result of prosthodontic treatment ${ }^{29}$. Accordingly, the purpose o the present investigation was to compare patient satisfaction and OHRQoL of patients restored with milled bar and rigid telescopic attachments for mandibular implant supported overdentures.

\section{MATERIALS AND METHODS}

\section{Patient Selection}

Eight totally edentulous participants (4 men and 4 women) with maladaptation to conventional mandibular dentures (range of age from 53 and 69 years) were recruited for this investigation. The included participants were unsatisfied with the retention and stability of existing mandibular prosthesis due to mandibular atrophy. The steps and objectives of the research were informed to all participants then an informed consent was obtained. The study was conducted according to principles stated in the Helsinki Declaration. Inclusion criteria include: adequate bone quantity and quality in the interforaminal area to receive standard diameter implants of at least $3.7 \mathrm{~mm}$ as detected by cone beam computerized tomography (CBCT), 2) Adequate interocclusal distance with adequate restoration space (at least $15 \mathrm{~mm}$ from the occlusal plane to the mucosa of the residual ridge) to permit construction of telescopic and bar attachments, 3) Non-smoker patients, 4) Implant sites were required to have at least 4 months of healing following tooth removal prior to implant installation. The protocol of the study was reviewed and approved by the Faculty of dentistry Bani-suef university research Ethics committee (Approved number \#FDBSUREC/12052019/AS. Exclusion criteria were; 1) Persons with a history of microvascular or macrovascular complications, 2) Patients with advanced cardiovascular disease, liver dysfunction, blood dyscrasias or underwent anticoagulant therapy, 3) Patients with bone metabolic diseases as diabetes mellites, osteoporosis or long-term radiation therapy. The patients were asked to participate in this study without prior knowledge of which type of attachments they were going to receive. Patients were randomly assigned into 2 groups using random generated numbers in Excel spread sheet. The randomization and allocation were performed to balance patients' characters (age, sex, height of mandibular ridges) between groups at base line without significant difference. Group 1: in which the overdentures were connected to the implants with rigid telescopic attachments. Group 2: in which the overdentures were connected to the implants with milled bar attachments.

\section{Surgical and prosthetic procedures}

Gutta perchae markers were added to the existing mandibular denture with at buccal, labial and lingual polished surfaces and the denture was used as a radiographic template. Each participant underwent a dual scan protocol using CBCT (VGI, QR, Verona, Italy). The first scan was made while each participant wears the dentures and closing in centric occlusion to ensure accurate adaptation of the dentures to the mucosa. The second scan was made to the lower denture alone. Selection of appropriate implant dimensions (length and width) was made from implant library software (OnDemand3D software, Cybermed, Seoul, Korea), then correct implant position and orientation was made ( 2 implants in premolar areas just anterior to the mental foramina, and 2 implants in lateral incisor area of the mandible). The treatment plan was saved as DICOM (Digital Imaging and Communications in Medicine) file format (stl files). The plane was sent to the guide manufacture. Overlapping of the images were made, then metallic sleeves were positioned over implant sites and a mucosal supported strolithographic surgical guide was constructed using prototyping technology.

All patients administered prophylactic antibiotics ( $2 \mathrm{~g}$ of amoxicillin 1 hour before surgery) and mouth rinse with a $0.12 \%$ chlorhexidine digluconate (15 minutes prior to surgery). Four implants (Dentarum, Germany) were inserted in the interforaminal 
area of the mandible using the flapless surgical approach. The surgical guide and the standardized surgical kit provided by the manufacture of the guide (In2Guide) were used for implant osteotomy preparation. The kit contained drills of increasing diameters that fits precisely into the sleeves of the template. Appropriate healing abutments were selected according gingival height. Three weeks postoperatively, the patient's existing mandibular dentures were relieved over implant sites and refitted to the mucosa using a tissue conditioner.

Due the rigid nature of the tested attachments, the impression procedure must register the mucosa under compression and relate the impression to the implants passively ${ }^{30}$. After 3 months of osseointegration, mandibular preliminary impression was made with irreversible hydrocolloid material (CA 37, Cavex Holland BV, Haarlem, Netherlands) and poured to obtain a diagnostic cast on custom trays were fabricated with an open area in the implant region using autopolymerizing acrylic resin. Impression transfer copings with long screws were threaded into the implants ${ }^{31}$. The copings were splinted in patient mouth using a special resin with no dimensional changes (Duralay, Reliance Dental MFG Co, Worth, IL, USA) to prevent movement of the impression posts during the impression removal. After border molding of the trays, light body rubber base impression material was injected around the impression transfer and the impression of the alveolar mucosa was made with medium consistency rubber base impression material (Impregum Soft, 3M ESPE). Implant analogues were attached to the impression coping with the long fixation screw and the final impressions were poured with hard stone (ZETA, Orthodontic Stone; WhipMix. Corp, Louisville, $\mathrm{Ky}$ ).

For rigid telescopic attachments group, 4 precious metal abutments (Dentaurum, Germany) were threaded to the implant analogues. The plastic portions of the abutments were waxed and the wax was milled with special burs (which have $0^{\circ}$ inclination) using a milling device (Confident, Bangalore, India) to give the primary (inner) copings $(6 \mathrm{~mm}$ in height and $5 \mathrm{~mm}$ in diameter). The 4 wax patterns were milled to make their circumferential walls parallel to each other's in mesiodistal and buccolingual direction regardless implant inclination. The wax was invested, cast in cobalt chromium alloy ${ }^{32-34}$ (Heraenium Pw, HeraeusKulzer GmbH, Hanau, Germany) and refined by milling again. The outer copings were waxed over the inner crowns, connected by framework for metal reinforcement, invested and cast in the same alloy ${ }^{32-34}$ (fig1). For Milled bar attachments, plastic caps were threaded to bar abutments. The bar resin was made with $10 \mathrm{~mm}$ posterior cantilever extensions using Duralay resin. The dimensions of the bar were $5 \mathrm{~mm}$ in height and $4 \mathrm{~mm}$ in width with $1 \mathrm{~mm}$ between the bar and mucosa for oral hygiene. Rounded bar plastic segments were added to the top of bar on the anterior segment and on the cantilevers. The plastic bar was milled and cast with Co-Cr alloy (Wironit, BEGO Bremer Goldschlägerei Wilh. Herbst GmbH, Germany) and milled again. The bar tried in patient mouth to ensure passive fit then returned to the cast. Wax pattern for the bar housing was made over the finished bar and cast using the same alloy. Plastic clips (RHEIN 83. Italy) were cemented in the metal housings for additional retention (fig 2).

Any pressure areas that prevent seating of the secondary copings or metal housings of the bars were identified and removed using a disclosing material (Fit Checker). Record blocks were constructed over telescopic and milled bar attachments and used to record maxillomandibular relationship. Try in was completed and packing of acrylic resin was made over the secondary copings of telescopic attachments and metal housing of milled bar attachments. Dentures were processed in usual manner. The occlusion was refined by remounting procedures and instructions of oral hygiene were given to all participants after prosthesis delivery. 


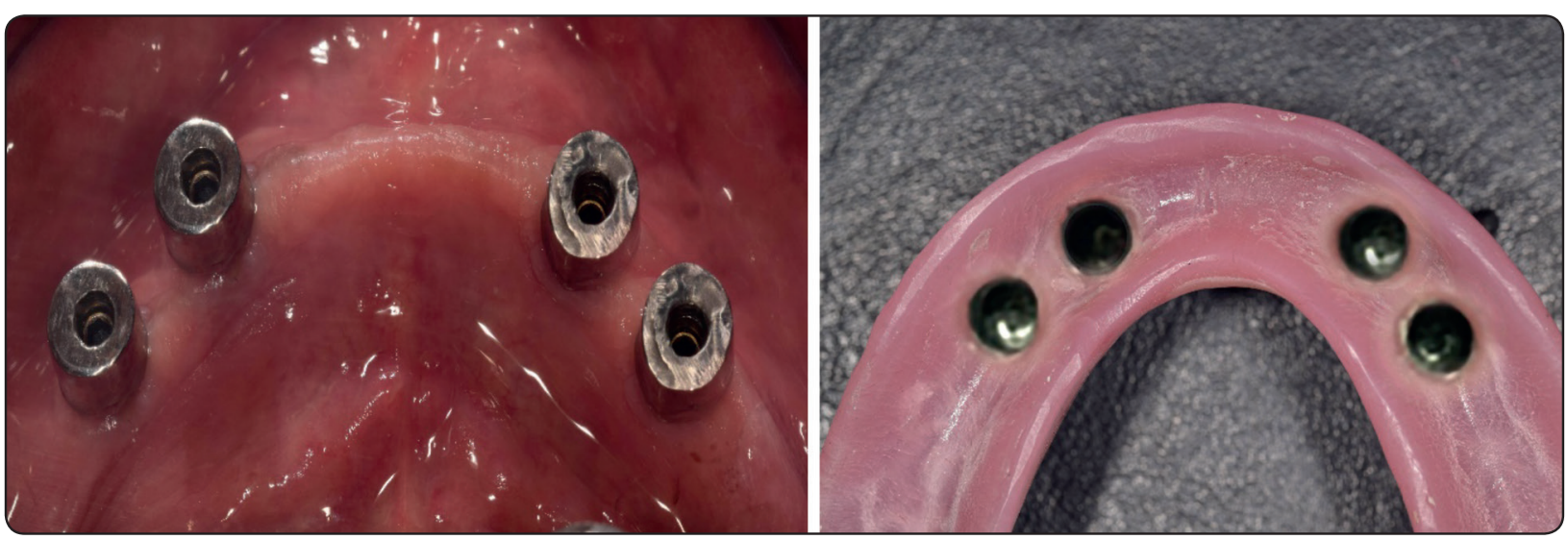

Fig. (1) Telescopic overdentures, a; in patient mouth, b, fitting surface

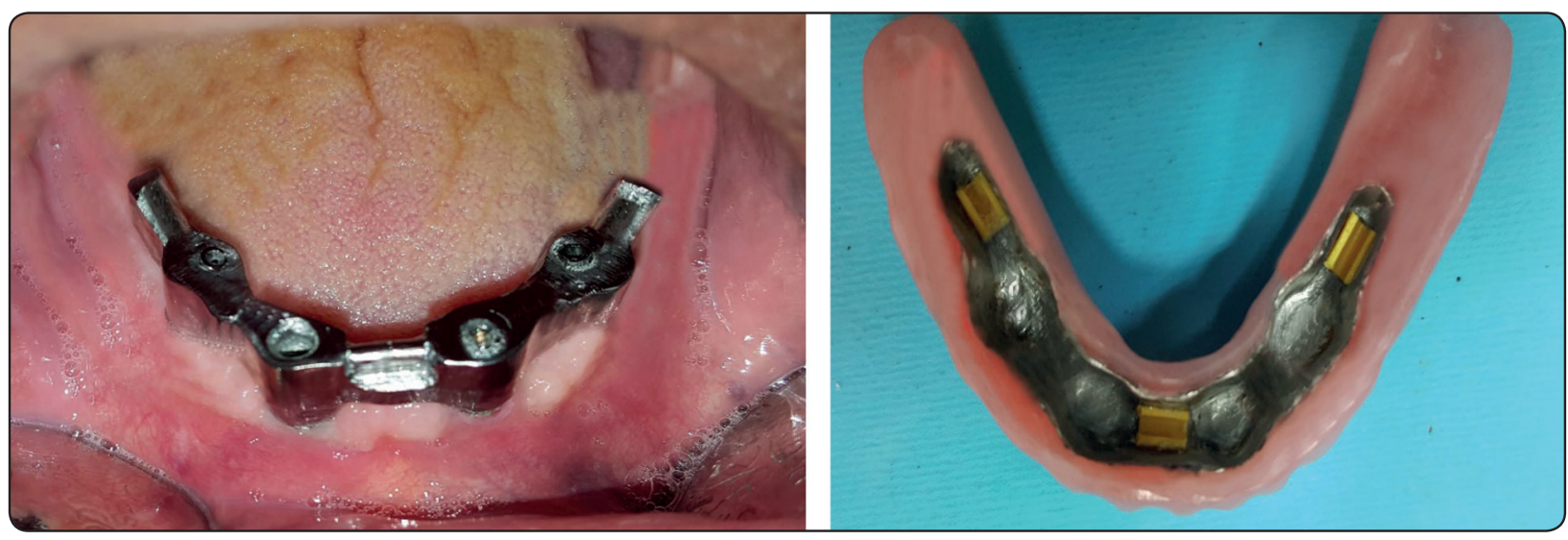

Fig. (2) Milled bar overdentures, a; in patient mouth, b, fitting surface

\section{Evaluation of participant satisfaction and Oral} Health Related Quality Profile:

Patient satisfaction was evaluated using a visual analogue scale Linkert ${ }^{35}$ in which each participant put a mark on $10 \mathrm{~cm}$ scale corresponding to his satisfaction of specific item of the questionnaire (included in table1). Higher VAS scores indicate high satisfaction and lower scores indicate low satisfaction. Oral health related quality of life was measured using oral health impact profile (OHIP14) questions $^{36}$. The OHIP contains 7 domains and each domain contain 2 questions (table 2). Participant responses to each question of OHIP (included in table 2) were never (1), hardly ever (2), occasionally (3), fairly often (4) and very often
(5). Lower scores indicated higher satisfaction, vice versa. All questionaires were translated and given in arabic to all participants. Meaasurements were performed 3 months after using each of telescopic and milled bar overdentures to enhance good muscle control.

\section{Statistical analysis}

To compare patient satisfaction and oral health impact profle between the attachments, MannWhiteny test was utilized. The software package used for data analysis was SPSS ${ }^{\circledR}$ version 25 (SPSS Inc., Chicago, IL, USA). The level of significance was adjusted at $5 \%$. 


\section{RESULTS}

The follow up period was short (3 months), thus all participants attend the evaluation visits without dropouts. The survival rate of the implants was $100 \%$ in each group. No implant failures occurred.

Comparison of patient satisfaction using visual analouge scale between overdentures was presented in table 1. Milled bar showed significant higher satisfaction scores with respect to overdenture retention than telescopic overdentures, while telescopic overdentures showed significant higher satisfaction scores with overdenture cleaning compared to milled bar. No significant differnce between the 2 types of overdentures was noted regarding other questionaire of VAS (Satisfaction with overdentures in general, satisfaction with overdentures compared to natural dentition, overdenture stability, overdenture occlusion, comfort with speech, comfort with mastication, appearance, ease of handling the overdenture, feeling that prosthesis apart of you, and absence of embarrassment).
The comparison of the 7 domains of OHIP between overdentures is presented in fig 3. Telescopic overdentures recorded higher satisfaction regarding Function problems and Physically detected disability than milled bar overdentures. No significant differnece in other domains of OHIP (Physical pain, Psychological discomfort, Psychologically detected disability, Socially detected disability, and Handicapping) was noted between overdentures. Comparison of the 14 questions of OHIP between overdentures is presented in table 2. Telescopic overdentures showed higher satisfaction regarding pronounciation of sounds, comfort on eating than milled bar overdentures. No significant differnce between overdentures were noted for other OHIP questions (Sensation of taste, Pain or ache, Selfconsciousness, Sensation of tense, Unsatisfaction with food, Interruption of meal, Unable to relax, Embarrassed, Irritation with others, Difficult doing job, Life generally, and Difficulty in function well).

TABLE (1) Comparison of VAS (mm) for both overdentures

\begin{tabular}{|c|c|c|c|c|c|}
\hline & & $\begin{array}{l}\text { escopic } \\
\text { dentures }\end{array}$ & & $\begin{array}{l}\text { led bar } \\
\text { lentures }\end{array}$ & $\mathrm{P}$ value \\
\hline & mean & St deviation & mean & St deviation & \\
\hline Satisfaction with overdentures & 85 & 5.4 & 84 & 4.3 & .23 \\
\hline $\begin{array}{l}\text { Satisfaction with overdentures compared to } \\
\text { natural dentition }\end{array}$ & 86 & 6.9 & 89 & 7.8 & .33 \\
\hline Overdenture retention & 82 & 9.7 & 95 & 7.6 & $<.001 *$ \\
\hline Overdenture stability & 94 & 6.1 & 95 & 6.6 & .84 \\
\hline Overdenture occlusion & 89 & 5.6 & 88 & 5.1 & .54 \\
\hline Overdenture cleaning & 91 & 4.5 & .74 & 9.8 & $<.001 *$ \\
\hline Comfort with speech & 85 & 6.8 & 87 & 7.2 & .68 \\
\hline Comfort with mastication & 91 & 9.8 & 93 & 8.6 & .74 \\
\hline Appearance & 88 & 8.4 & 86 & 7.8 & .94 \\
\hline Ease of handling the overdenture & 94 & 5.6 & 93 & 6.4 & .75 \\
\hline Prosthesis apart of you & 91 & 7.8 & 90 & 6.5 & .88 \\
\hline Absence of embarrassment & 94 & 6.9 & 92 & 5.3 & .15 \\
\hline
\end{tabular}

*P is significant at $.05 \%$ 
TABLE 2: Comparison of Oral health impact profile for both overdentures

\begin{tabular}{|c|c|c|c|c|c|c|}
\hline & & \multicolumn{2}{|c|}{ Telescopic overdentures } & \multicolumn{2}{|c|}{$\begin{array}{l}\text { Milled bar } \\
\text { overdentures }\end{array}$} & \multirow[t]{2}{*}{ P value } \\
\hline & & mean & St deviation & mean & St deviation & \\
\hline \multirow[t]{2}{*}{ Function problems } & $\begin{array}{l}\text { OHIP1 } \\
\text { Pronunciation of sound }\end{array}$ & 2.70 & .67 & 3.90 & .74 & $.003^{*}$ \\
\hline & $\begin{array}{l}\text { OHIP2 } \\
\text { Sensation of taste }\end{array}$ & 2.60 & .70 & 2.80 & .63 & .45 \\
\hline \multirow[t]{2}{*}{ Physical pain } & $\begin{array}{l}\text { OHIP3 } \\
\text { Pain or ache }\end{array}$ & 2.70 & .67 & 2.50 & .71 & .54 \\
\hline & $\begin{array}{l}\text { OHIP4 } \\
\text { Comfort on eating }\end{array}$ & 2.50 & .71 & 3.90 & .74 & $.002 *$ \\
\hline \multirow[t]{2}{*}{$\begin{array}{l}\text { Psychological } \\
\text { discomfort }\end{array}$} & $\begin{array}{l}\text { OHIP5 } \\
\text { Self-consciousness }\end{array}$ & 2.80 & .63 & 2.90 & .57 & .84 \\
\hline & $\begin{array}{l}\text { OHIP6 } \\
\text { Sensation of tense }\end{array}$ & 2.80 & .79 & 3.10 & .74 & .68 \\
\hline \multirow[t]{2}{*}{$\begin{array}{l}\text { Physically detected } \\
\text { disability }\end{array}$} & $\begin{array}{l}\text { OHIP7 } \\
\text { Unsatisfaction with } \\
\text { food }\end{array}$ & 2.89 & .60 & 3.33 & .50 & .37 \\
\hline & $\begin{array}{l}\text { OHIP8 } \\
\text { Interruption of meal }\end{array}$ & 2.73 & .65 & 3.36 & .67 & .051 \\
\hline \multirow[t]{2}{*}{$\begin{array}{l}\text { Psychologically } \\
\text { detected disability }\end{array}$} & $\begin{array}{l}\text { OHIP9 } \\
\text { Unable to relax }\end{array}$ & 2.80 & .79 & 2.70 & .67 & .80 \\
\hline & $\begin{array}{l}\text { OHIP10 } \\
\text { Embarrassed }\end{array}$ & 2.80 & .79 & 2.70 & .67 & .80 \\
\hline \multirow[t]{2}{*}{$\begin{array}{l}\text { Socially detected } \\
\text { disability }\end{array}$} & $\begin{array}{l}\text { OHIP11 } \\
\text { Irritation with others }\end{array}$ & 2.80 & .63 & 2.70 & .67 & .70 \\
\hline & $\begin{array}{l}\text { OHIP12 } \\
\text { Difficult doing job }\end{array}$ & 2.90 & .74 & 3.10 & .57 & .49 \\
\hline \multirow[t]{2}{*}{ Handicapping } & $\begin{array}{l}\text { OHIP13 } \\
\text { Life generally }\end{array}$ & 3.20 & .92 & 3.30 & .82 & .83 \\
\hline & $\begin{array}{l}\text { OHIP14 } \\
\text { Difficulty in function } \\
\text { well }\end{array}$ & 2.80 & .63 & 3.00 & .67 & .49 \\
\hline
\end{tabular}

*P is significant at $.05 \%$ 


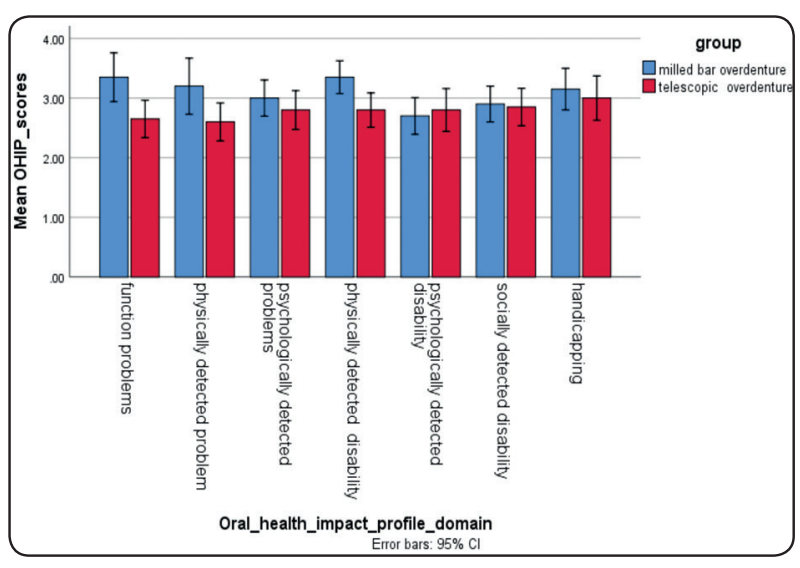

Fig. (3) Comparison of OHIP domains between overdentures

\section{DISCUSSION}

The survival rate of the implants was $100 \%$ in each group. In agreement with our finding, Krennmair et al. ${ }^{37}$ found a high implant survival/ success rate $(100 \%)$ for 4 implants inserted in the interforaminal area and supporting mandibular overdenture with rigid telescopic and milled bar attachments attachments. The high survival rate of implants was attributed to the high bone quantity and density in the interforaminal area of the mandible and location away from vital structures which give good implant prognosis ${ }^{12-15}$

Milled bar showed significant higher satisfaction with overdenture retention than telescopic attachments. This may be due to milled bar drives its retention from friction between metal hosing and the bar together with additional retention of plastic clips, while telescopic attachments drive the retention from frictional contact between primary and secondary copings. Although plastic clips are subjected to wear after repeated insertions and removals, this was not observed in this study due to the short foloow up period. Therefore, long term evaluation of the retention of milled bar is recommended to detect if plastic clips need replacement or not. On the other hand telescopic overdentures showed significant higher satisfaction with overdenture cleaning compared to milled bar. This could be attributed to the unsplinted nature of the attachments provide circular cleaning capability with no areas with limited access for oral hygiene resulting in healthier gingival conditions than with bars ${ }^{27}$. Conversly, bar attachments are associated with greater gingival coverage which induce high plaque accumulation, and gingival inflamation ${ }^{27}$.

No significant differnce between the 2 types of overdentures was noted regarding satisfaction in general, satisfaction compared to natural dentition, stability, occlusion, comfort with speech, comfort with mastication, appearance, ease of handling the overdenture, feeling that prosthesis apart of you, and absence of embarrassment. The lack of significant differnce between the attachments may be attributed to the increased denture retention and stability which make the patients feel that their prostheis is similar to natural dentition and feel that both prostheses a part of them ${ }^{38}$. The increased retention and stability of the dentures also provide good mastication, occlusion and speech thanks to good masticatory force transmission, (which always takes place axial to the implants) and phonetics ${ }^{28,39}$. Both overdentures provide adequate lip support by proper waxing up of the labial flanges of the dentures, and therrefore, no differnce in satisfation with esthetics was noted. The increased stability and ethetics of both overdentures make the participants not embrassed when participating dialy activities. The telescopic nature of metal housing and milled bar (bar group) and primary and secondary copings (telescopic group) provides self-finding mechanism of both attachments which facilitate ease of handiling and prostheis insertion and removal especially with eldery participants with decreased manual dexitrity and systemic diseases ${ }^{26}$

For OHRQoL, telescopic overdentures recorded higher satisfaction regarding function problems of OHIP (pronounciation of sounds) and physically detected disability (comfort on eating) than milled bar overdentures. This could be attributed to the unsplinted property of telescopic attachments 40 which allow implant placement in a defined location that is less restricted than with splinted structures. ${ }^{26 \text {, }}$ 
${ }^{41}$ Splinted bar attachments connecting implants in the anterior mandible may restrict the tongue space and thus result in discomfort with eating and may have effect on pronounciation of sounds, than single telescopic attachments ${ }^{41-44}$. This problem are evident with posterior implants especially with cantilever extensions of milled bar $^{26}$. The use of telescopic connectors for prosthesis stabilization provides several advantages owing to their unsplinted nature. Placement is less restricted to a certain localization in comparison with splinted constructions, where the bar has to be about 20-mm long and in a straight line across the anterior segment of the mandible which can restrict tongue space ${ }^{26}$. With regard to the comfort of chewing, overdentures retained on bars can drastically reduce the space available for tongue function ${ }^{45}$. This is an obvious merit for implant prostheses retained on telescopic crowns over the splinted bar ${ }^{27}$.

No significant differnce between overdentures were noted for other OHIP questions as sensation of taste, pain or ache, self-consciousness, sensation of tense, unsatisfaction with food, interruption of meal, unable to relax , embarrassed, irritation with others, difficult doing job, life generally, and difficulty in function well. This may be attributed to the increased retention and stability of the prothesis after implant installation and attachments connection compared to the previous conventional dentures. Those dentures were unstable due to mandibular ridge atrophy and the patients were unsatisfied with their old dentures. The improved stability and retention by connection of the overdenture to the implants reduce discomfort, increase bite forces and increase the ability to chew food during compared to conventional denture. On the other hand, compression of the soft tissue under the denture during chewing and biting together with reduced denture stability limits muscle and masticatory functions ${ }^{46}$. In agreement with this explanation, Khalid et al. ${ }^{29}$, reported that implant supported overdentures with telescopic crown or locator attachments showed significant improvement in patients' OHIP compare to base line ratings and also found a stronger association of mandibular bone height (degree of ridge atrophy) with improvement in Oral health related quality of life regardless the type of tttachment system used. In a recent study, Elsyad et $\mathrm{al}^{47}$. reported significant improvement in all domains and questions of OHIP when milled bar attachments was used compared to previous conventional denture.

The limitations of this study include the small sample size, the short follow up period, and the lack of control group. Therefore, future randomized controlled clinical trials with sufficient follow up period (to test the effect of time on patient satisfaction) are recommended to ensure the long term finding of this study. Also, inclusion of conventional denture group as a control may be needed to compare patient satisfaction and OHIP of the tested attachments with conventional complete denture.

\section{CONCLUSION}

Within the limits of this study, both telescopic and milled bar mandibular overdentures achieve high patient satisfaction and oral health related quality of life. However, milled bar overdentures are advantageous in terms of overdenture retention and telescopic overdentures are advantageous in terms of cleaning, comfort on eating and pronunciation of sounds.

\section{REFERENCES}

1. Feine JS, Carlsson GE, Awad MA, Chehade A, Duncan WJ, Gizani S, et al. The McGill consensus statement on overdentures. Mandibular two-implant overdentures as first choice standard of care for edentulous patients. Gerodontology. 2002;19:3-4.

2. Thomason JM, Feine J, Exley C, Moynihan P, Muller F, Naert I, et al. Mandibular two implant-supported overdentures as the first choice standard of care for edentulous patients--the York Consensus Statement. Br Dent J. 2009;207:185-6.

3. Wismeyer D, van Waas MA, Vermeeren JI. Overdentures supported by ITI implants: a 6.5-year evaluation of patient satisfaction and prosthetic aftercare. Int J Oral Maxillofac Implants. 1995;10:744-9. 
4. Mericske-Stern RD, Taylor TD, Belser U. Management of the edentulous patient. Clin Oral Implants Res. 2000;11 Suppl 1:108-25.

5. Cordaro L, di Torresanto VM, Petricevic N, Jornet PR, Torsello F. Single unit attachments improve periimplant soft tissue conditions in mandibular overdentures supported by four implants. Clin Oral Implants Res. 2013;24:536-42.

6. de Jong MH, Wright PS, Meijer HJ, Tymstra N. Posterior mandibular residual ridge resorption in patients with overdentures supported by two or four endosseous implants in a 10-year prospective comparative study. Int J Oral Maxillofac Implants. 2010;25:1168-74.

7. Krennmair G, Krainhofner M, Piehslinger E. The influence of bar design (round versus milled bar) on prosthodontic maintenance of mandibular overdentures supported by 4 implants: a 5-year prospective study. Int J Prosthodont. 2008;21:514-20.

8. Elsyad MA, Hegazy SA, Hammouda NI, Al-Tonbary GY, Habib AA. Chewing efficiency and electromyographic activity of masseter muscle with three designs of implant-supported mandibular overdentures. A cross-over study. Clin Oral Implants Res. 2014;25:742-8.

9. Martinez-Lage-Azorin JF, Segura-Andres G, Faus-Lopez J, Agustin-Panadero R. Rehabilitation with implant-supported overdentures in total edentulous patients: A review. J Clin Exp Dent. 2013;5:e267-72.

10. El-Sheikh AM, Hobkirk JA. Force transmission in bar-retained implant-stabilised mandibular over-dentures: an invitro study. Eur J Prosthodont Restor Dent. 2002;10:173-8.

11. Wright PS, Watson RM. Effect of prefabricated bar design with implant-stabilized prostheses on ridge resorption: a clinical report. Int J Oral Maxillofac Implants. 1998;13:77-81.

12. Batenburg RH, Meijer HJ, Raghoebar GM, Van Oort RP, Boering G. Mandibular overdentures supported by two Branemark, IMZ or ITI implants. A prospective comparative preliminary study: one-year results. Clin Oral Implants Res. 1998;9:374-83.

13. Davis DM, Rogers JO, Packer ME. The extent of maintenance required by implant-retained mandibular overdentures: a 3-year report. Int J Oral Maxillofac Implants. 1996;11:767-74.

14. Mericske-Stern R. Clinical evaluation of overdenture restorations supported by osseointegrated titanium implants: a retrospective study. Int $\mathbf{J}$ Oral Maxillofac Implants. 1990;5:375-83.
15. Naert I, Quirynen M, Theuniers G, van Steenberghe D. Prosthetic aspects of osseointegrated fixtures supporting overdentures. A 4-year report. J Prosthet Dent. 1991;65:671-80.

16. Hebel KS, Galindo D, Gajjar RC. Implant position record and implant position cast: minimizing errors, procedures and patient visits in the fabrication of the milled-bar prosthesis. J Prosthet Dent. 2000;83:107-16.

17. Tipton PA. The milled bar-retained removable bridge implant-supported prosthesis: a treatment alternative for the edentulous maxilla. J Esthet Restor Dent. 2002;14:208-16.

18. Ercoli C, Graser GN, Tallents RH, Hagan ME. Alternative procedure for making a metal suprastructure in a milled bar implant-supported overdenture. J Prosthet Dent. 1998;80:253-8.

19. Galindo DF. The implant-supported milled-bar mandibular overdenture. J Prosthodont. 2001;10:46-51.

20. Krennmair G, Krainhofner M, Piehslinger E. Implantsupported mandibular overdentures retained with a milled bar: a retrospective study. Int J Oral Maxillofac Implants. 2007;22:987-94.

21. Dudic A, Mericske-Stern R. Retention mechanisms and prosthetic complications of implant-supported mandibular overdentures: long-term results. Clin Implant Dent Relat Res. 2002;4:212-9.

22. Bedrossian E, Sullivan RM, Fortin Y, Malo P, Indresano T. Fixed-prosthetic implant restoration of the edentulous maxilla: a systematic pretreatment evaluation method. J Oral Maxillofac Surg. 2008;66:112-22.

23. Bueno-Samper A, Hernandez-Aliaga M, Calvo-Guirado JL. The implant-supported milled bar overdenture: a literature review. Med Oral Patol Oral Cir Bucal. 2010;15:e375-8.

24. Heckmann SM, Winter W, Meyer M, Weber HP, Wichmann MG. Overdenture attachment selection and the loading of implant and denture-bearing area. Part 2: A methodical study using five types of attachment. Clin Oral Implants Res. 2001;12:640-7.

25. Heckmann SM, Winter W, Meyer M, Weber HP, Wichmann MG. Overdenture attachment selection and the loading of implant and denture-bearing area. Part 1: In vivo verification of stereolithographic model. Clin Oral Implants Res. 2001;12:617-23.

26. Heckmann SM, Schrott A, Graef F, Wichmann MG, Weber HP. Mandibular two-implant telescopic overdentures. Clin Oral Implants Res. 2004;15:560-9.

27. Eitner S, Schlegel A, Emeka N, Holst S, Will J, Hamel J. Comparing bar and double-crown attachments in implantretained prosthetic reconstruction: a follow-up investigation. Clin Oral Implants Res. 2008;19:530-7. 
28. Hoffmann O, Beaumont C, Tatakis DN, Zafiropoulos GG. Telescopic crowns as attachments for implant supported restorations: a case series. J Oral Implantol. 2006;32:291-9.

29. Khalid T, Yunus N, Ibrahim N, Elkezza A, Masood M. Patient-reported outcome and its association with attachment type and bone volume in mandibular implant overdenture. Clin Oral Implants Res. 2017;28:535-42.

30. Gregory-Head B, LaBarre E. Two-step pick-up impression procedure for implant-retained overdentures. J Prosthet Dent. 1999;82:615-6.

31. Zarb GA, Jansson T. Prosthodontic procedures. In: Brånemark, P.I., Zarb, G.A., Albrektsson, T. eds. Tissue Integrated Prostheses - Osseointegration in Clinical Dentistry $\mathrm{p}$ 251-270. 1985; Quintessence Publishing Co. Inc. Chicago, United States of America.

32. Besimo CH, Graber G, Fluhler M. Retention force changes in implant-supported titanium telescope crowns over longterm use in vitro. J Oral Rehabil. 1996;23:372-8.

33. Ohkawa S, Okane H, Nagasawa T, Tsuru H. Changes in retention of various telescope crown assemblies over longterm use. J Prosthet Dent. 1990;64:153-8.

34. Weigl P, Hahn L, Lauer HC. Advanced biomaterials used for a new telescopic retainer for removable dentures: Ceramic vs. Electroplated Gold Copings: Part I. In Vitro Tribology Effects. J Biomed Mater Res. 2000;53:320-36.

35. Awad MA, Feine JS. Measuring patient satisfaction with mandibular prostheses. Community Dent Oral Epidemiol. 1998;26:400-5.

36. Slade GD, Spencer AJ. Development and evaluation of the Oral Health Impact Profile. Community Dent Health. 1994;11:3-11.

37. Krennmair G, Suto D, Seemann R, Piehslinger E. Removable four implant-supported mandibular overdentures rigidly retained with telescopic crowns or milled bars: a 3-year prospective study. Clin Oral Implants Res. 2012;23:481-8.

38. Allen F, McMillan A. Food selection and perceptions of chewing ability following provision of implant and conventional prostheses in complete denture wearers. Clin Oral Implants Res. 2002;13:320-6.
39. Zafiropoulos GG, Hoffmann O. Five-year study of implant placement in regenerated bone and rehabilitation with telescopic crown retained dentures: a case report. J Oral Implantol. 2009;35:303-9.

40. Krennmair G, Weinlander M, Krainhofner M, Piehslinger E. Implant-supported mandibular overdentures retained with ball or telescopic crown attachments: a 3-year prospective study. Int J Prosthodont. 2006;19:164-70.

41. Spiekermann H, Jansen VK, Richter EJ. A 10-year followup study of IMZ and TPS implants in the edentulous mandible using bar-retained overdentures. Int J Oral Maxillofac Implants. 1995;10:231-43.

42. Mericske-Stern R, Steinlin Schaffner T, Marti P, Geering AH. Peri-implant mucosal aspects of ITI implants supporting overdentures. A five-year longitudinal study. Clin Oral Implants Res. 1994;5:9-18.

43. Naert I, Alsaadi G, van Steenberghe D, Quirynen M. A 10year randomized clinical trial on the influence of splinted and unsplinted oral implants retaining mandibular overdentures: peri-implant outcome. Int J Oral Maxillofac Implants. 2004;19:695-702.

44. Naert I, Gizani S, Vuylsteke M, Van Steenberghe D. A 5-year prospective randomized clinical trial on the influence of splinted and unsplinted oral implants retaining a mandibular overdenture: prosthetic aspects and patient satisfaction. J Oral Rehabil. 1999;26:195-202.

45. Bernhart G, Koob A, Schmitter M, Gabbert O, Stober T, Rammelsberg P. Clinical success of implant-supported and tooth-implant-supported double crown-retained dentures. Clin Oral Investig. 2011.

46. Elsyad MA, Khairallah AS. Chewing efficiency and maximum bite force with different attachment systems of implant overdentures: a crossover study. Clin Oral Implants Res. 2017; 28:677-82.

47. Abdou EM, Elgamal M, Mohammed Askar O, Youssef Al-Tonbary G. Patient satisfaction and oral health-related quality of life (OHRQoL) of conventional denture, fixed prosthesis and milled bar overdenture for All-on-4 implant rehabilitation. A crossover study. Clin Oral Implants Res. 2019.(In press) 